\title{
Testing the ecological stability of ectomycorrhizal symbiosis: effects of heat, ash and mycorrhizal colonization on Pinus muricata seedling performance
}

\author{
Kabir G. Peay • Thomas D. Bruns • \\ Matteo Garbelotto
}

Received: 13 May 2009 /Accepted: 13 October 2009 / Published online: 24 October 2009

(C) The Author(s) 2009. This article is published with open access at Springerlink.com

\begin{abstract}
Understanding how abiotic conditions mediate the outcome of biotic interactions is a key question in community ecology. This is particularly interesting in the case of mutualisms because changing environmental conditions may be a source of evolutionary or ecological instability in the relationship between symbiotic partners. For the mycorrhizal symbiosis, elevated nutrient levels may make the carbon cost to plants of supporting mycorrhizal fungi outweigh the benefits of mycorrhizal nutrient acquisition. In this study, we simulated the effects of post-fire nutrient enrichment on the ectomycorrhizal symbiosis between Rhizopogon occidentalis and Pinus muricata by using factorial combinations of soil heating, ash addition and mycorrhizal colonization. In general, the presence of $R$. occidentalis and the heat and ash treatments increased growth of $P$. muricata
\end{abstract}

Responsible Editor: Erik A. Hobbie.

Electronic supplementary material The online version of this article (doi:10.1007/s11104-009-0200-1) contains

supplementary material, which is available to authorized users.

K. G. Peay $\cdot$ T. D. Bruns $\cdot$ M. Garbelotto

Department of Environmental Science,

Policy and Management, University of California,

Berkeley, CA 94720, USA

K. G. Peay $(\bowtie) \cdot$ T. D. Bruns

Department of Plant and Microbial Biology,

University of California,

Berkeley, CA 94720, USA

e-mail: kpeay@berkeley.edu seedlings. However, significant interactions between the treatments indicated that there were contextdependent effects on seedling growth. Soil heating increased soil mineral nitrogen content, but did not decrease the benefit of mycorrhizal colonization relative to unheated controls. This appeared to be driven by a decrease in the proportion of the root system occupied by $R$. occidentalis, indicating that host-plants can optimize colonization in a way that maximizes growth. Because seedlings in heat-treated soils were larger than unheated controls, reduced percent colonization did not cause any decrease in fungal biomass in heat-treated soils. Since there was no decrease in the performance of either partner, our results show that, in this system, ectomycorrhizal mutualisms are likely robust within the natural degree of environmental variability caused by moderate intensity wildfires.

Keywords Bishop pine · Point Reyes · Competition . Economic model $\cdot$ Mutualism $\cdot$ Cooperation

\section{Introduction}

Understanding how abiotic conditions mediate the outcome of biotic interactions is a key question in community ecology (Agrawal et al. 2007). Many studies in this area have focused on how environmental context affects competitive interactions between members of the same guild (Chesson and Warner 1981; 
Hutchinson 1961; Park 1954; Wiens 1977). Demonstrating environmental conditionality led to its recognition as a factor promoting species coexistence in diverse assemblages. However, less work has been done on the effects of environmental context on mutualisms (Bronstein 1994; Piculell et al. 2008; Setala et al. 1997). This is a major oversight given the recent recognition that mutualistic interactions may be as important as competitive ones in determining community structure and function (Stachowicz 2001). This question is particularly interesting in the context of mutualisms because changing environmental conditions may have the potential to move mutualistic interactions towards parasitism and may be a source of evolutionary instability (Herre et al. 1999; Johnson 1993; Sachs et al. 2004).

The mycorrhizal symbiosis is an ancient and ubiquitous component of terrestrial plant communities and is perhaps the most widespread example of cooperation in nature (Simon et al. 1993; Smith and Read 1997). Most mycorrhizal symbiosis involves the exchange of plant photosynthates for soil nutrients (e.g. nitrogen and phosphorous) acquired by the fungal partner (Smith and Read 1997). The ectomycorrhizal symbiosis is among the most common and is associated with dominant tree species in many ecosystems (Horton and Bruns 2001). It occurs in a broad range of climatic and edaphic conditions, spanning the geographic range from the boreal to the tropics (Alexander and Lee 2005; Hobbie and Hobbie 2006; Ishida et al. 2007; Lilleskov et al. 2004; Morris et al. 2008). Within an ecosystem, ectomycorrhizal symbiosis also occurs across a wide range of spatial and temporal variation in environmental conditions.

Biological markets are based on the mutually beneficial exchange of commodities or services between two individuals (Noë and Hammerstein 1995). In interspecific mutualisms, as in international trade, exchanges are beneficial because the partners differ in ability and cost of obtaining various resources, a concept also known as 'comparativeadvantage' (Hoeksema and Schwartz 2003; Schwartz and Hoeksema 1998). Under such economic models of mutualism, the amount of trade and degree of benefit is directly related to the relative cost of goods traded by the two partners. Environmental perturbations that affect resource abundance may thus significantly alter the cost-benefit structure of interspecific mutualisms. Studies of agricultural systems have shown that high levels of fertilization can select for arbuscular mycorrhizal fungi that are less beneficial or even parasitic on their host plants (Johnson 1993; Johnson et al. 1997). Additionally, high levels of nitrogen fertilization can decrease colonization by ectomycorrhizal fungi (Beckford et al. 1985; Molina and Chamard 1983; Smith and Read 1997) and lead to significant change in ectomycorrhizal community structure (Lilleskov et al. 2001, 2002; Parrent and Vilgalys 2007). However, these studies focused on anthropogenically caused resource gradients, and it is unclear whether the natural range of environmental variability experienced by hosts and fungi can significantly alter the cost-benefit structure of ectomycorrhizal mutualism. There is disagreement about the evolutionary stability of the ectomycorrhizal habit for fungi, and phylogenetic scenarios showing both frequent gains and losses or gains but no losses have been proposed (Bruns and Shefferson 2004; Hibbett et al. 2000). Better understanding of the costs and benefits of ectomycorrhizal symbiosis at the ecological scale may help shed light on the plausibility of these evolutionary scenarios.

Fire is one of the most common sources of natural, large-scale environmental variation in many ectomycorrhizal forests (Pyne et al. 1996; Sugihara et al. 2006). In this study we simulated the effects of fire on the ectomycorrhizal symbiosis between Rhizopogon occidentalis Zeller \& Dodge and Pinus muricata D. Don. P. muricata is a closed-cone pine and recruits almost exclusively after large, stand replacing fires. Because all parent trees are dead, post-fire seedlings must be colonized by ectomycorrhizal propagules that remain in the soil or by aerial dispersal from living stands located in the adjacent landscape. Studies in this system show that the majority of immediate postfire colonization comes from resident soil propagules (Baar et al. 1999). Species in the genus Rhizopogon are dominant members of this spore bank and are among the most frequent colonizers on establishing post-fire seedlings or in bioassay studies (Baar et al. 1999; Horton et al. 1998; Izzo et al. 2006b; Peay et al. 2007). While the effects of fire are spatially and temporally variable, fires generally lead to an increase in availability of key plant nutrients, such as nitratenitrogen $\left(\mathrm{NO}_{3}-\mathrm{N}\right)$, ammonium-nitrogen $\left(\mathrm{NH}_{4}-\mathrm{N}\right)$, phosphorous $(\mathrm{P})$, potassium $(\mathrm{K})$, magnesium $(\mathrm{Mg})$ and calcium (Ca) (Certini 2005; Neary et al. 1999; St. John and Rundel 1976; Tryon 1948). Two potential 
sources of post-fire nutrient enrichment are soil heating and ash deposition (Raison 1979). In this study, we manipulated both soil heating and ash deposition to see how they would independently and interactively affect growth and nutrient status of seedlings in the presence or absence of ectomycorrhizal fungi. In particular, we were interested to see if fire-related nutrient increases would lead to fungal parasitism in the ectomycorrhizal symbiosis. In addition we examined the effects of these treatments on colonization levels of the fungus. Past work in this system (e.g. Kennedy and Peay 2007) has indicated some degree of plant control over ectomycorrhizal colonization levels. For this reason we hypothesized that ectomycorrhizal symbiosis would remain mutualistic via the plants' ability to control fungal colonization levels to optimize growth based on changes in resource acquisition costs. Such a result would be evidence in favor of a biological market model of mycorrhizal symbiosis (Hoeksema and Schwartz 2003; Schwartz and Hoeksema 1998).

\section{Methods}

\section{Study system}

Our study investigated the Pinus muricata D. Don (Bishop pine) ectomycorrhizal system found at Point Reyes National Seashore. Point Reyes National Seashore is located in west Marin County, California $\left(38^{\circ} 04^{\prime} \mathrm{N}, 122^{\circ} 50^{\prime} \mathrm{W}\right)$. The area has a Mediterranean climate with cool, wet winters and warm, dry summers. Mean annual temperature at the coast is around $11^{\circ} \mathrm{C}$, with normal daily maximum around $18^{\circ} \mathrm{C}$ in September and normal daily minimum around $5^{\circ} \mathrm{C}$ in January. Near the coast, P. muricata is one of the major ectomycorrhizal host plants, and forms monodominant tree stands that intergrade with non-ectomycorrhizal coastal grasslands and scrub.

\section{Experimental design}

This study was designed as a factorial experiment to examine the effects of ectomycorrhizal colonization and fire on the growth of $P$. muricata seedlings. Because of the difficulty in manipulating these factors independently in the field, we carried out the experiment in a growth chamber. We manipulated the presence of ectomycorrhizal (EM) fungi by using live field soil collected from areas without ectomycorrhizal inoculum and using spores collected from ectomycorrhizal fruit bodies. We manipulated the two major components of fire, soil heating and ash addition, using a drying oven and ash collected from prescribed burns at Point Reyes. The experimental setup included all possible treatment combinations $(\mathrm{EM} \pm$, Heat,$\pm \mathrm{Ash} \pm$ ) and 16 replicates per treatment for a total of 128 experimental units $(2 \times 2 \times 2 \times 16)$.

\section{Soil treatments}

On July 12, 2006, approximately 201 of field soil was collected from the D-Ranch historical site at Point Reyes National Seashore $\left(38^{\circ} 01^{\prime} 56^{\prime \prime} \mathrm{N}, 122^{\circ} 56^{\prime} 56^{\prime \prime} \mathrm{W}\right)$. This site has soils similar to those naturally colonized by $P$. muricata, but is located $5 \mathrm{~km}$ from the nearest stand of P. muricata and consists of non-ectomycorrhizal grasses and scrub. Previous work has found this area to be generally free of ectomycorrhizal propagules (Kennedy et al. 2007). It was important to find naturally EM free soils because other methods of sterilization (e.g. irradiation or autoclaving) might change the biotic and chemical properties of the soil and would confound our fire simulation treatments. After collection, the soil was stored at $4{ }^{\circ} \mathrm{C}$ for $\sim 24 \mathrm{~h}$, at which time it was sieved through a $2 \mathrm{~mm}$ soil sieve and mixed thoroughly in a sterilized container. On July 14 we separated out two 4-liter batches of soil. One batch was mixed $1: 1$ by volume $(v / v)$ with autoclaved sand $\left(120^{\circ} \mathrm{C}, 45 \mathrm{~min}\right.$ wet, $25 \mathrm{~min}$ dry $)$ and put directly into $150 \mathrm{~mL}$ "cone-tainer" pots (hereafter "pots"; Stuewe and Sons, Corvallis, Oregon, USA). The other batch was subjected to heat treatments modified from Izzo et al. (2006a). Briefly, this consisted of spreading a $1 \mathrm{~cm}$ layer of soil into a sterile metal pan and heating it in a soil drying oven. During the experiment, soil temperatures were monitored continuously using an external thermocouple. Soils temperatures between 65 and $70^{\circ} \mathrm{C}$ are common in low to moderate intensity fires and have strong biological effects without total sterilization (Neary et al. 1999). For this reason, soil temperatures were allowed to reach $70^{\circ} \mathrm{C}$ (approximately $10-15 \mathrm{~min}$ ), then placed in an incubator set at $45^{\circ} \mathrm{C}$ for $40 \mathrm{~min}$, and finally allowed to cool to room temperature. This procedure replicates the rapid heating and slow cooling experienced by soils during low to moderate intensity wildfire. Two batches were 
required to produce enough soil for the experiment. Soil temperatures were recorded every $30 \mathrm{~s}$ using a HOBO datalogger equipped with two thermoprobes that was placed inside the soil treatments.

After the soil cooled to room temperature it was mixed 1:1 $v / v$ with sterile sand and placed into pots. Pots from both heated and unheated soil treatments then received 3 pre-germinated $P$. muricata seeds that were then covered with a thin layer of sand. Half of the seedlings from each heat treatment were then randomly designated to receive mycorrhizal fungi $(\mathrm{EM}+)$, and within each of these four treatments half of the pots were selected randomly to receive an ash treatment. The ash treatment consisted of 1.5 grams (dry weight) ash taken from four prescribed burn sites at Point Reyes. The prescribed burns were conducted in late summer or early fall and the ash was collected within one week of each burn. Ash collection occurred 2-3 months before mushroom fruiting season at Point Reyes, thus is it unlikely that the ash acquired EM inoculum in this time period. One and a half grams is the approximate amount of ash needed for this surface area of soil to replicate the post-fire ash levels observed at Point Reyes after the Vision Fire (Grogan et al. 2000b). After ash addition, all pots were watered lightly, covered with plastic wrap, and placed in a growth chamber set at $16 \mathrm{~h}$ day, $8 \mathrm{~h}$ dark and $18^{\circ} \mathrm{C}$. After approximately one week the seedlings emerged and the plastic wrap was removed. Seedlings were watered once weekly to capacity and rotated frequently within the growth-chamber to ensure that there was no effect of chamber position.

On August 15, all seedlings assigned to the EM + treatment group were given $2 \mathrm{~mL}$ of a spore slurry from the ectomycorrhizal species $R$. occidentalis. All seedlings assigned to the EM - treatment were given $2 \mathrm{~mL}$ of distilled water $\left(\mathrm{dH}_{2} \mathrm{O}\right)$. The spore slurry was made from multiple independent collections of $R$. occidentalis fruit bodies in 10-year-old stands of $P$. muricata at Point Reyes during the winter of 2006. Fruit bodies were homogenized in a stainless steel blender with $\mathrm{dH}_{2} 0$, filtered through multiple layers of cheesecloth, spore concentration assessed with a haemocytometer, and then stored at $4^{\circ} \mathrm{C}$. The spore concentration of the slurry we used was $5.3 \times 10^{6}$ spores per $\mathrm{mL}$, so each seedling received approximately 10.6 million spores, which has been shown to be sufficient to ensure colonization (Bruns et al. 2009). On the same day that these treatments were carried out all pots were weeded down to a single seedling. To avoid disturbing the root system and to ensure no bias in seedling selection, weeding was done by decapitating all seedlings other than the one closest to the middle of the pot.

The effects of the simulated fire treatments on soil chemistry were assessed as part of a parallel experiment examining the response of the ectomycorrhizal fungal community to fire. Detailed methods and results are published in Peay et al. (2009). Briefly, we performed a $2 \times 2$ factorial experiment using the same heat and ash treatments with five replicates per treatment combination $(2$ treatments $\times 2$ levels $\times 5$ replicates $=20$ pots total) and analyzed soil chemistry. Ash addition significantly increased soil $\mathrm{pH}, \mathrm{P}, \mathrm{Ca}$, $\mathrm{Mg}$, and $\mathrm{K}$. Both heat and ash significantly increased soil $\mathrm{NO}_{3}-\mathrm{N}$ but ash addition decreased soil $\mathrm{NH}_{4}-\mathrm{N}$. Results from Peay et al. (2009) are summarized in Table 1.

\section{Seedling harvest}

In March of 2007, approximately nine months after planting, we harvested seedlings from all treatments. Seedlings were first presoaked in deionized water while still in their pots so that soil could be washed away easily while leaving the root system intact. Next, the root system was examined under a $40 \mathrm{X}$ dissecting microscope to assess ectomycorrhizal colonization status. For seedlings that received the EM+ treatment, one representative root was placed into distilled water, flash frozen in liquid nitrogen, and lyophilized for later molecular analysis if necessary. The remaining colonized roots were removed and placed in a coin envelope. The uncolonized portion of the root system and the shoots were separated and placed into coin envelopes as well. All three components of biomass, EM roots, uncolonized roots, and shoot system were then dried at $64^{\circ} \mathrm{C}$ for 2 days and weighed. We did encounter some ectomycorrhizal contamination in two treatments $(\mathrm{EM}-/$ Heat + / Ash + and EM- / Heat $+/$ Ash-). All seedlings in these treatments with $>0.1 \%$ root weight colonization were discarded, leaving $n=9$ and $n=3$ for the respective treatments. Replication for the other six treatment combinations was either 15 or 16 .

We also assessed percent needle nitrogen content for each seedling. Dried needle tissue was placed in separate $2.0 \mathrm{~mL}$ screw cap amalgamator tubes with 
Table 1 Effects of soil heating (Heat) and ash addition (Ash) on soil chemistry, based on data in Peay et al. (2009). Means are based on 5 replicates and shown $+/-1 \mathrm{SE}$

\begin{tabular}{|c|c|c|c|c|}
\hline Variable & $\begin{array}{l}\text { Heat }+ \\
\text { Ash+ }\end{array}$ & $\begin{array}{l}\text { Heat- } \\
\text { Ash }+\end{array}$ & $\begin{array}{l}\text { Heat }+ \\
\text { Ash- }\end{array}$ & $\begin{array}{l}\text { Heat- } \\
\text { Ash- }\end{array}$ \\
\hline $\mathrm{pH}$ & $5.0(0.3)^{\mathrm{A}}$ & $5.0(0.2)^{\mathrm{A}}$ & $4.6(0.3)^{\mathrm{B}}$ & $4.6(0.3)^{\mathrm{B}}$ \\
\hline$\% \mathrm{OM}$ & $3.7(0.6)$ & $3.8(0.5)$ & $3.8(0.8)$ & $3.9(0.6)$ \\
\hline $\mathrm{P}(\mathrm{ppm})$ & $30.8(3.1)^{\mathrm{A}}$ & $38.8(1.6)^{\mathrm{A}}$ & $25.0(1.5)^{\mathrm{B}}$ & $24.4(1.5)^{\mathrm{B}}$ \\
\hline $\mathrm{Ca}(\mathrm{ppm})$ & $376.0(8.5)^{\mathrm{A}}$ & $340.6(3.7)^{\mathrm{A}}$ & $269.8(9.7)^{\mathrm{B}}$ & $220.4(3.8)^{\mathrm{B}}$ \\
\hline $\mathrm{Mg}(\mathrm{ppm})$ & $134.0(2.1)^{\mathrm{A}}$ & $139.4(3.2)^{\mathrm{A}}$ & $98.6(6.5)^{\mathrm{B}}$ & $80.8(2.5)^{\mathrm{B}}$ \\
\hline $\mathrm{K}(\mathrm{ppm})$ & $237.0(3.5)^{\mathrm{A}}$ & $253.4(4.5)^{\mathrm{A}}$ & $107.4(6.3)^{\mathrm{B}}$ & $100.4(2.9)^{\mathrm{B}}$ \\
\hline CEC (meq/100 g) & $7.0(0.7)^{\mathrm{A}}$ & $7.0(0.6)^{\mathrm{A}}$ & $6.1(1.4)^{\mathrm{B}}$ & $5.2(0.8)^{\mathrm{B}}$ \\
\hline $\mathrm{NH}_{4}-\mathrm{N}(\mathrm{ppm})$ & $34.2(1.5)^{\mathrm{A}}$ & $33.2(1.6)^{\mathrm{A}}$ & $40.4(2.3)^{\mathrm{B}}$ & $36.4(1.0)^{\mathrm{B}}$ \\
\hline $\mathrm{NO}_{3}-\mathrm{N}(\mathrm{ppm})$ & $25.6(0.9)^{\mathrm{a}}$ & $27.2(1.4)^{\mathrm{a}}$ & $30.8(1.8)^{\mathrm{a}}$ & $14.0(1.9)^{\mathrm{b}}$ \\
\hline
\end{tabular}

Significant differences among treatments are denoted with letters. Upper case letters indicate a significant Ash main effect and lower case letters indicate a significant Heat $\times$ Ash interaction. There were no significant independent main effects of Heat on any variables $\mathrm{pH}$, organic matter $(O M)$, weak Bray phosphorous $(P)$, extractable calcium $(\mathrm{Ca})$, extractable magnesium $(\mathrm{Mg})$, extractable potassium $(\mathrm{K})$, cation exchange capacity $(\mathrm{CEC})$, nitrate-nitrogen $\left(\mathrm{NO}_{3}-\mathrm{N}\right)$ and ammonium-nitrogen $\left(\mathrm{NH}_{4}-\mathrm{N}\right)$

glass beads and ground in a Mixer Mill MM 301 (Retsch, Haan, Germany). Six milligrams were measured into a tin capsule (COSTEK, Valencia, California, USA) and percent carbon and nitrogen determined using a CE Elantech NC2100 elemental analyzer (Lakewood, New Jersey, USA).

\section{Statistical analysis}

To see how growth of $P$. muricata seedlings was affected by the experimental treatments we used a three-way fixed factor analysis of variance (ANOVA) including main effects and interactions for all treatment variables. Because of the unequal replication in treatments caused by mycorrhizal contamination, we report Type III sums of squares (which is the most appropriate for unbalanced designs) and marginal means (i.e. group means un-weighted by sample size) for all treatment groups. All response variables were checked for normality and transformed when necessary. All variables had homogenous variance as assessed with the Fligner-Killeen test $(P>0.05)$ (Conover et al. 1981). For significant interactions we determined differences between groups with Tukey's HSD test based on marginal means.

For seedlings that received the EM+ treatment, we tested to see whether heat and ash affected mycorrhizal colonization using a two-way fixed factor
ANOVA. Percent root weight colonization was calculated as (weight of EM roots) / (weight of EM roots + non-EM roots $) \times 100$. While this colonization metric is calculated differently than the \% root tip or $\%$ root length metrics used in many studies, expressing colonization in terms of root weight is biologically meaningful, repeatable, and may be less sensitive to differences in root tip morphology between species of EM fungi (Kennedy et al. 2006; Kennedy and Peay 2007; Kennedy et al. 2009).

All statistical tests and graphics were produced using the program R v.2.7.2 (R Core Development Team 2008) and considered significant at $P<0.05$.

\section{Results}

The significant Heat $\times$ Ectomycorrhizal interaction on seedling total biomass (Table 2) indicated that the magnitude of these effects varied depending on the presence of the other treatment. Seedlings grown with both heated soils and ectomycorrhizal fungi were significantly larger than expected from the additive effects of soil heating or ectomycorrhizal fungi (Fig. 1). Overall, seedlings grown in heated soils (Mean $\pm 1 \mathrm{SE}$; Heated $=0.86 \pm 0.04 \mathrm{~g}$, Non-Heated $=$ $0.50 \pm 0.03 \mathrm{~g}$ ) and in the presence of $R$. occidentalis (Mean $\pm 1 \mathrm{SE}$; Ectomycorrhizal $=0.98 \pm 0.03 \mathrm{~g}$, Non- 
Table 2 P-values for treatment effects on the total biomass and $\%$ needle nitrogen content of Pinus muricata seedlings. Results are based on a three-way ANOVA using Type III sums of squares. Experimental treatments are soil heating (Heat), ash addition (Ash) and inoculation with the ectomycorrhizal fungus Rhizopogon occidentalis (EM)

\begin{tabular}{lcc}
\hline Treatment & $\%$ Needle N Pr $(>\mathrm{F})$ & Total biomass $\operatorname{Pr}(>\mathrm{F})$ \\
\hline Heat & $0.040^{*}$ & $<0.001^{*}$ \\
Ash & 0.619 & 0.355 \\
EM & $<0.001^{*}$ & $<0.001^{*}$ \\
Heat $\times$ Ash & 0.172 & $0.049^{*}$ \\
Heat $\times$ EM & 0.305 & $0.010^{*}$ \\
Ash $\times$ EM & $0.001^{*}$ & 0.144 \\
Heat $\times$ Ash $\times$ EM & 0.091 & 0.080
\end{tabular}

Significant treatment effects $(P<0.05)$ are indicated with an asterisk

mycorrhizal $=0.39 \pm 0.04 \mathrm{~g})$ were larger than respective control seedlings (Fig. S1). Ash addition only had positive effects on total seedling biomass in tandem with soil heating (Table 2, Fig. 1).

Soil heating, ash addition and presence of ectomycorrhizal fungi all had significant effects on seedling needle nitrogen (Table 2). Soil heating caused a small but significant reduction in percent needle $\mathrm{N}$ (Table 2; Mean $\pm 1 \mathrm{SE}$; Heated $=1.26 \pm 0.03 \%$, Non-Heated $=$ $1.31 \pm 0.02 \%$ ). The effects of ash depended on the presence of ectomycorrhizal fungi, as evident from a significant interaction between ash addition and presence of $R$. occidentalis (Table 2, Fig. 2). Ash addition had no effect on $\mathrm{N}$ content of needles in the presence of $R$. occidentalis but decreased $\mathrm{N}$ content in its absence (Fig. 2). Overall, ectomycorrhizal fungi strongly increased percent needle $\mathrm{N}$ (Table 2; Mean $\pm 1 \mathrm{SE}$; Ectomycorrhizal $=1.60 \pm 0.02 \%$, Non-mycorrhizal $=$ $0.97 \pm 0.03 \%$ ).

Soil heating caused a significant reduction in the percentage of seedling root weight colonized by $R$. occidentalis $\left(\mathrm{F}_{1,58}=7.06, P=0.01\right.$; Mean $\pm 1 \mathrm{SE}$; Heated $=52 \pm 2 \%$, Non-Heated $=63 \pm 2 \%$ ). There were no effects of Ash or an Ash $\times$ Heat interaction on the percentage of root-weight colonized $(P>0.05)$. While the soil heating treatment did reduce $\%$ root weight colonized by $R$. occidentalis, there was no effect of Heat or Ash on the absolute root biomass colonized $\left(\mathrm{F}_{3,58}=1.429, P=0.24\right.$, Mean $\pm 1 \mathrm{SE}$; Heated $=0.27 \mathrm{~g} \pm$ 0.02 , Non-Heated $=0.22 \mathrm{~g} \pm 0.02$, Ash $=0.24 \mathrm{~g} \pm 0.02$, No Ash $=0.25 \mathrm{~g} \pm 0.02)$.

\section{Discussion}

Soil heating, ash addition and the presence of $R$. occidentalis had interactive effects on the growth and nutrition of $P$. muricata seedlings. In general, all three treatments tended to increase biomass of $P$. muricata seedlings. This can be explained by the effect of these treatments in increasing plant available nutrients (Smith and Read 1997; St. John and Rundel 1976;

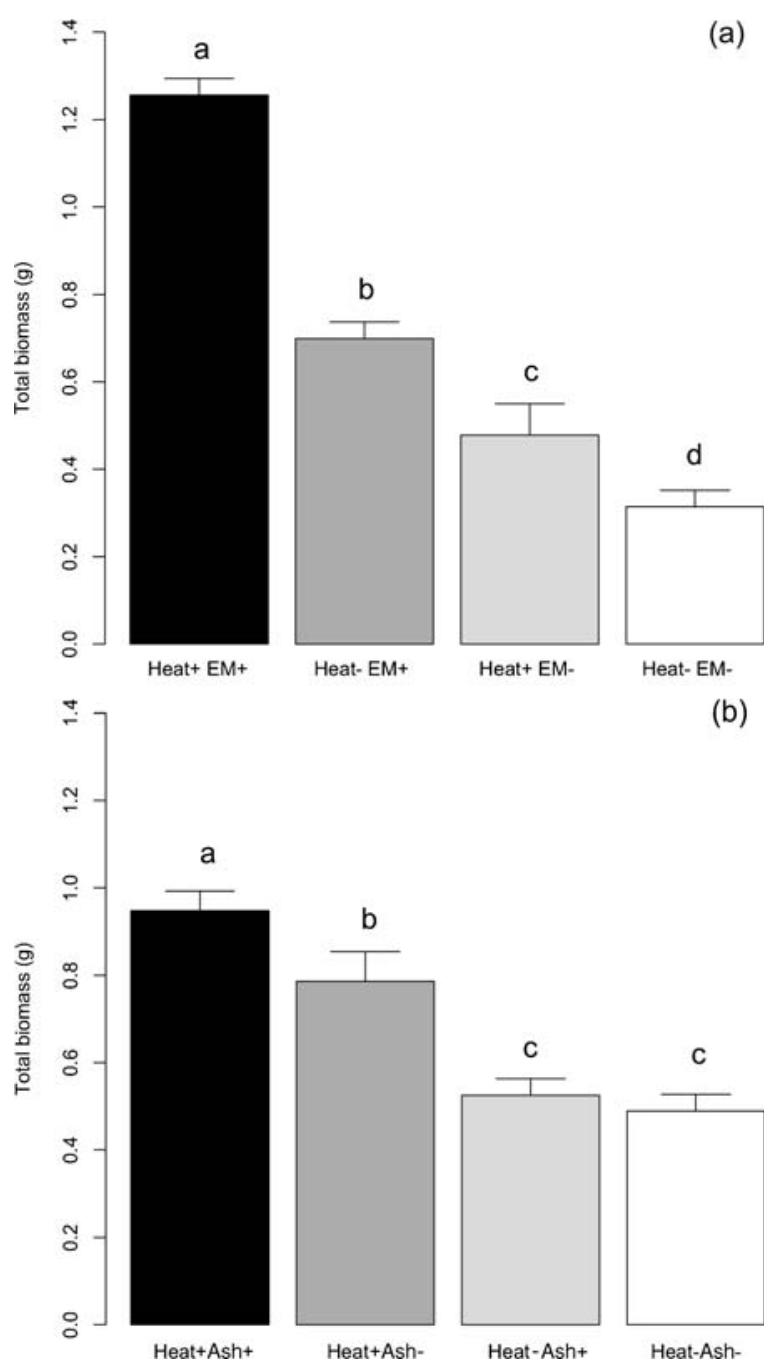

Fig. 1 Interactive treatment effects on total biomass of Pinus muricata seedlings. Panels show the effects of soil heating (Heat) and inoculation with the ectomycorrhizal fungus Rhizopogon occidentalis (EM) (a), and soil heating and ash addition (Ash) (b). Marginal means $\pm 1 \mathrm{SE}$ are displayed, but ANOVA and post-hoc tests were based on log-transformation of total biomass. Letters indicate significant differences based on a Tukey HSD test $(P<0.05)$ 


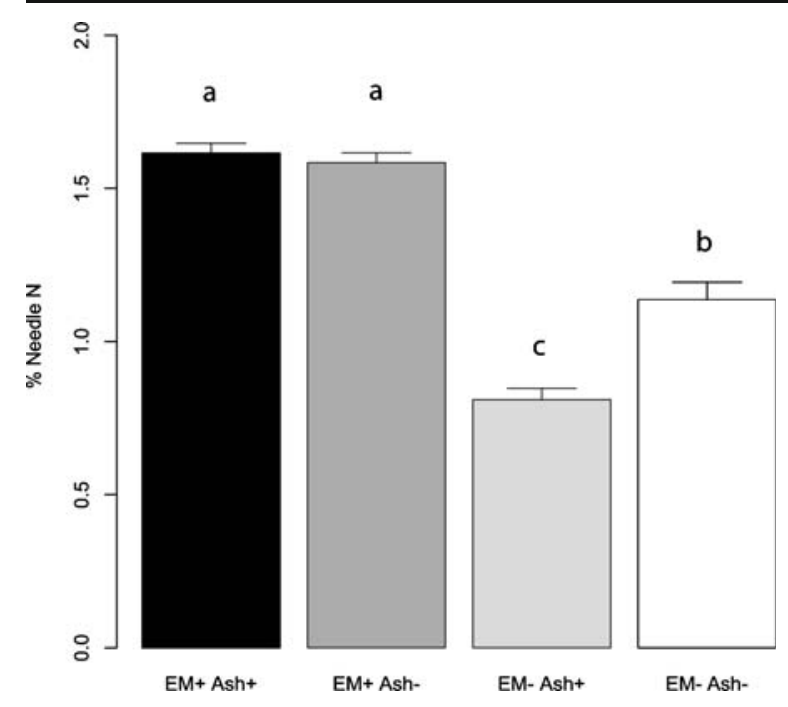

Fig. 2 Effects of inoculation with the ectomycorrhizal fungus Rhizopogon occidentalis (EM) and ash addition (Ash) on \% needle N content of Pinus muricata seedlings. Marginal means \pm $1 \mathrm{SE}$ are displayed. Letters indicate significant differences based on a Tukey HSD test $(P<0.05)$

Tryon 1948). These effects were strongest for presence of $R$. occidentalis and soil heating, and weakest for ash addition. Against the backdrop of general increases in plant growth, however, all three treatments exhibited context-dependent effects as evidenced by many significant interactions. These results provide further evidence that environmental context plays an important role in interspecific mutualisms (Bronstein 1994).

Biological markets are based on the exchange of commodities or services between two individuals (Noë and Hammerstein 1995), where the degree of benefit is linked to the comparative advantage the traders have obtaining various resources (Hoeksema and Schwartz 2003; Schwartz and Hoeksema 1998). Such models appear well suited for mycorrhizal mutualisms, where plants have an advantage in carbon capture and fungi have enzymatic and morphological (i.e. filamentous hyphae) advantages in foraging for soil nutrients (Smith and Read 1997). Both soil heating and presence of $R$. occidentalis increased seedling nitrogen availability and growth of P. muricata seedlings (Table 1, Fig. 1). Under such circumstances, economic models of mutualism might predict a decrease in the benefits of mycorrhizal colonization in heat-treated soils. However, we observed the opposite trend - the growth benefits of mycorrhizal colonization actually increased in heat- treated soils (Fig. 1). Ash addition-which increased levels of $\mathrm{NO}_{3}-\mathrm{N}, \mathrm{P}, \mathrm{K}, \mathrm{Ca}$ and $\mathrm{Mg}$ in soils-might also have been expected to decrease the benefits of mycorrhizal colonization, but no such effect was observed.

We believe there are four scenarios that could lead to this outcome under a market model of nitrogen exchange; (1) non-saturating $\mathrm{N}$ benefits to seedlings, (2) temporal disjunction in the availability of $\mathrm{N}$ from soil heating and ectomycorrhizal colonization, (3) plant optimization of mycorrhizal colonization levels, or (4) enhanced dependence on mycorrhizal acquisition of other mineral nutrients as $\mathrm{N}$ becomes less limiting. While this study was not designed to distinguish between these scenarios, our results are not equally consistent with all four explanations. Our data indicate that non-saturating N-benefits (Scenario 1) are unlikely in this study. While there is a strong positive relationship between $\%$ needle $\mathrm{N}$ and total biomass across the whole dataset (slope $=0.57, r^{2}=$ $0.25, P<0.001$ ), this result primarily reflects the difference between mycorrhizal and non-mycorrhizal seedlings. In mycorrhizal seedlings colonized by $R$. occidentalis there is only a very weak, negative correlation between $\%$ needle $\mathrm{N}$ and total biomass (slope $=-0.70, r^{2}=0.06, P=0.049$ ). This negative correlation does not imply that $\mathrm{N}$ reduces growth. Rather, it is likely an artifact of exhaustion of available soil $\mathrm{N}$ within the $150 \mathrm{~mL}$ pots by large seedlings (estimated total soil $\mathrm{N}$ is $90 \mathrm{mg}$ per pot) and dilution of seedling $\mathrm{N}$ as biomass increases with further growth. Regardless, the lack of a positive relationship between growth and \% needle $\mathrm{N}$ for colonized seedlings suggests that there is a saturation point for benefits from nitrogen acquisition from ectomycorrhizal fungi.

Temporal disjunction in the availability of $\mathrm{N}$ from soil heating and ectomycorrhizal colonization (Scenario 2) may be more plausible since most studies find that increases in mineral nitrogen content following fire are fairly short lived (Certini 2005; Grogan et al. 2000b; Hart et al. 2005; Neary et al. 1999). Because mycorrhizal colonization of $P$. muricata seedlings by $R$. occidentalis usually takes 4-6 weeks (Peay, personal observation), early increases in nitrogen availability in heated soils probably lead to significant increases in early seedling growth. While we did not harvest seedlings early in the experiment, personal observations indicated that growth benefit from the heat 
treatment was greatest in the first few months of the study (Peay, personal observation). Mycorrhizal colonization beyond the early pulse of nitrogen availability would allow seedlings to maintain rapid growth for the remainder of the experiment, and the exponential nature of plant growth could explain the non-additive interaction between the benefits of heat and ectomycorrhizal colonization. The temporal separation of $\mathrm{N}$ pools (direct uptake vs EM uptake) would also decrease $\mathrm{N}$ saturation at any given time point, which should strengthen the mutualism.

We also find some evidence for plant optimization of mycorrhizal colonization levels (Scenario 3) in our study. If a portion of seedling nitrogen demand is available more cheaply through direct uptake, seedlings should take up available nitrogen directly on their own and then supplement the remainder from ectomycorrhizal symbiosis. This scenario should lead to lower levels of mycorrhizal colonization in N-enriched settings. Wallander and Nylund $(1991,1992)$ found that nitrogen fertilization strongly decreased ectomycorrhizal biomass in and around roots of Pinus sylvestris, and suppression of mycorrhizal formation under high $\mathrm{N}$ conditions has been reported in other studies (Marx et al. 1977; Termorshuizen and Ket 1989). Our results show that heat treatments (which increase mineral $\mathrm{N}$ abundance) decreased \% ectomycorrhizal colonization. That seedlings grew to their largest sizes in this treatment suggests that seedlings were able to minimize costs and optimize growth by limiting their proportional investment in mycorrhizal colonization. Percent root weight colonized by $R$. occidentalis in this study $(\sim 50$ $60 \%$ ) was at the high end of the range observed in other studies ( $20-30 \%)$ using this method (Kennedy and Peay 2007; Kennedy et al. 2009), both of which used autoclaved soils. This difference between studies is consistent with our results since the heat from autoclaving likely also caused large nutrient releases. Despite the decrease in \% colonization caused by the soil heating treatment in this study, $R$. occidentalis did not suffer a decrease in absolute abundance because seedlings on heat-treated soils had a comparatively larger root system. To the extent that biomass correlates with fitness, this observation suggests that there was no net decrease in fitness from the fungal perspective despite lower proportional plant investment.

We did not measure the effects of colonization by $R$. occidentalis on uptake of other plant nutrients (such as $\mathrm{P}$ or $\mathrm{K}$ ) and so have no direct data regarding enhanced dependence on mycorrhizal acquisition after $\mathrm{N}$ limitation decreases (Scenario 4). This is a weakness of our study and would be an interesting area of exploration for further research. However, the results from the ash addition experiment do provide some indirect insight. The only effects of ash on seedling growth that we observed occurred in the Heat $+/$ Ash + treatment. This effect was relatively small despite the large increase in a number of key plant nutrients, including $\mathrm{NO}_{3}-\mathrm{N}, \mathrm{P}, \mathrm{Mg}, \mathrm{K}$ and $\mathrm{Ca}$, caused by ash addition (Table 1). While this result may seem surprising, Tryon (1948) found nearly identical results, with large changes in soil chemistry and no changes in seedling growth from experimental charcoal additions. While the effects of charcoal and ash on $\mathrm{N}$ cycling are highly variable (DeLuca and Sala 2006), DeLuca et al. (2006) found that under some circumstances charcoal addition can increase nitrification rates in forest soils. Thus, the effects of ash treatments reported in Peay et al. (2009) and shown in Table 1 do not seem anomalous. If non-N base cations were important in the mycorrhizal symbiosis in this study, we would expect some interaction between ectomycorrhizal colonization, seedling growth and ash addition. However, we found no effects of ash addition on seedling growth or colonization in ectomycorrhizal seedlings. The fact that heat and $R$. occidentalis both had strong positive effects on $\mathrm{N}$ availability and on seedling growth also reinforce the idea that $\mathrm{N}$ is the primary limiting nutrient in this system and the most important nutrient in this mycorrhizal symbiosis. However, given the limitations of our study this is certainly a topic that deserves more research.

We have focused the interpretation of this experiment primarily on an economic model of mutualism based on exchange of $\mathrm{N}$ between plant and fungus. However, it is likely that other biotic interactions play an important role in the results we observe. In particular, the decrease in $\%$ needle $\mathrm{N}$ observed in the Heat $-/ \mathrm{Ash}+$ treatments could be explained due to interactions with nonsymbiotic soil microorganisms (saprotrophic fungi and bacteria). If nutrient inputs from ash resulted in microbial proliferation and immobilization of plant available soil $\mathrm{N}$, this would explain the decrease in \% needle $\mathrm{N}$ we observe in the Ash $+/ \mathrm{EM}$ - treatment (Fig. 2). Similarly, the increase in $\mathrm{N}$ observed in the heat treatments is likely due to mineralization from the death of soil microbes. While we favor the market 
model interpretation of our results, it is possible that some of the growth effects seen in seedlings in the Heat $+/ \mathrm{EM}+$ treatment could be explained by reduced competitive effects on $R$. occidentalis from other soil microbes.

A number of recent studies have highlighted the need for investigation of the effects of spatial and temporal variation in the environment on the outcome of mutualistic interactions (Bronstein 1994, 2001; Egger and Hibbett 2004; Herre et al. 1999; Jones and Smith 2004). Much of the interest in this topic was generated by Bronstein's (1994) conclusion that conditional exploitation - the change of a normally ' + ' ' + ' to a ' + ' '-' interaction — should be fairly common in mutualisms that are affected by ecological context. In this sense, exploitation is synonymous with parasitism as used by other workers (e.g. Johnson et al. 1997). Ectomycorrhizal interactions occur in a wide range of environments and exhibit few of the characteristics thought to stabilize mutualisms, such as vertical transmission, genotypic uniformity and limited number of symbionts (Egger and Hibbett 2004; Herre et al. 1999), making conditional exploitation seem a likely outcome. While there are a number of good examples of host plant exploitation by arbuscular mycorrhizal fungi (Jones and Smith 2004; Klironomos 2002), the evidence for exploitation by ectomycorrhizal fungi is limited.

There is no doubt that conditionality exists in ectomycorrhizal symbiosis. Multiple studies have documented changes in the symbiosis between environments, fungal species, and even genotypes of the same species (Beckford et al. 1985; Burgess et al. 1994; Kennedy and Peay 2007; Nara 2006; Piculell et al. 2008; Zhou and Sharik 1997). However, true exploitation, i.e. decreases in plant growth relative to nonmycorrhizal controls, has primarily been demonstrated under artificial conditions involving heavy fertilization (Beckford et al. 1985; Hoeksema et al. 2009; Molina and Chamard 1983). Evidence that exploitation is common under semi-natural conditions is ambiguous. For example, Stenstrom et al. (1990) concluded that mycorrhizal inoculation decreased growth of field grown Pinus sylvestris seedlings, but their 'noninoculated' controls were extensively colonized by indigenous ectomycorrhizal fungi. Similarly, Zhou and Sharik (1997) interpret changes in fungal colonization across a light and nutrient gradient to be evidence for parasitism, but without any non-mycorrhizal reference plants for comparison. As the data from this study indicate, changes in colonization levels alone do not amount to parasitism.

Our results suggest that ectomycorrhizal symbiosis between P. muricata and Rhizopogon occidentalis appears to be fairly stable within the realm of environmental variability caused by moderate intensity wildfire. They also suggest that the symbiosis, and by extension ectomycorrhizal communities, may be more sensitive to the physical disturbances caused by soil heating rather than the nutrient fluxes resulting from ash and heat. Strong community response to heating and relative insensitivity to ash has been reported in a number of ectomycorrhizal community studies (Grogan et al. 2000a; Izzo et al. 2006a; Mahmood et al. 2002; Peay et al. 2009). Because fire is one of the major sources of change in soil nutrient status in many coniferous forests, these results may extend to a broader set of ecosystems than the one tested here. Despite a context dependent interaction between soil heating and ectomycorrhizal colonization, neither plant nor fungus appeared to suffer a reduction in overall performance. There is currently disagreement about the evolutionary stability of ectomycorrhizal symbiosis. Hibbett et al. (2000) found phylogenetic evidence for multiple losses of the ectomycorrhizal habit in basidiomycete fungi. Frequent losses of the mutualistic habit would suggest that mutualism is not a stable endpoint, and that the ecological conditions or evolutionary pressures capable of moving an intimate association from mutualism to other states (commensalism, parasitism) should occur with some frequency. However, Bruns and Shefferson (2004) analyzed more recent phylogenetic data and could not find a single unambiguous loss of the ectomycorrhizal habit. Our data suggest that the circumstances that would lead to exploitation occur infrequently in natural systems and support the assertion that the ectomycorrhizal habit is a stable evolutionary strategy (Bruns and Shefferson 2004).

Overall our results correspond very well with the market model of mycorrhizal mutualism outlined by Schwartz and Hoeksema (1998), where resource availabilities set the exchange rate for mutualistic services and partners can choose to trade in a way that optimizes fitness. The ability of symbionts to choose partners and set the amount of trade is thought to be one of the main stabilizing mechanisms in cooperative interactions (Herre et al. 1999; Sachs et al. 2004). 
Kennedy and Peay (2007) drew a similar conclusion on regulation of mutualistic exchange from the observation that mycorrhizal benefits decreased under simulated drought conditions, but fungal colonization never resulted in reduced host-fitness. In the reported instances of mycorrhizal parasitism in agricultural settings it appears that certain arbuscular mycorrhizal fungi are able to override their partner's ability to regulate mutualistic exchange (Johnson 1993; Johnson et al. 1997). Whether this phenomenon occurs amongst ectomycorrhizal fungi with any frequency in natural settings is unclear. The fact that our treatments (as well as those of Kennedy and Peay 2007) did not create conditions extreme enough to warrant cheating suggests that it does not. However, studies with a greater number of ectomycorrhizal symbionts and a greater range of environmental conditions are needed before this can be concluded with more certainty.

Acknowledgements We thank Wayne Sousa, Peter Kennedy, Jason Hoeksema, Natasha Hausmann and Erik Hobbie for comments on earlier versions of this manuscript, and Point Reyes National Seashore for supporting our research efforts there. Financial support was provided to KGP by the NASA Earth Systems Science Fellowship, the Chang Tien Lin Environmental Scholarship, and a Pacific Coast Science \& Learning Center grant. Financial support to TDB was provided by National Science Foundation grants DEB 236096 and DEB 0742868 .

Open Access This article is distributed under the terms of the Creative Commons Attribution Noncommercial License which permits any noncommercial use, distribution, and reproduction in any medium, provided the original author(s) and source are credited.

\section{References}

Agrawal AA, Ackerly DD, Adler F, Arnold AE, Caceres C, Doak DF, Post E, Hudson PJ, Maron J, Mooney KA, Power M, Schemske D, Stachowicz J, Strauss S, Turner MG, Werner E (2007) Filling key gaps in population and community ecology. Front Ecol Environ 5:145-152

Alexander IJ, Lee SS (2005) Mycorrhizas and ecosystem processes in tropical rain forest: implications for diversity. In: Burslem DFRP, Pinard MA, Hartley SE (eds) Biotic interactions in the tropics: their role in the maintenance of species diversity. Cambridge University Press, New York

Baar J, Horton TR, Kretzer A, Bruns TD (1999) Mycorrhizal recolonization of Pinus muricata from resistant propagules after a stand-replacing wildfire. New Phytol 143:409418

Beckford PR, Melhuish JH Jr, McIntosh MS (1985) Effects of nitrogen and phosphorous fertilization on growth and formation of ectomycorrhizae of Quercus alba and $Q$. rubra seedlings by Pisolithus tinctorius and Scleroderma auranteum. Can J Bot 63:1677-1680

Bronstein JL (1994) Conditional outcomes in mutualistic interactions. Trends Ecol Evol 9:214-217

Bronstein JL (2001) The exploitation of mutualisms. Ecol Lett 4:277-287

Bruns TD, Shefferson RP (2004) Evolutionary studies of ectomycorrhizal fungi: recent advances and future directions. Can J Bot 82:1122-1132

Bruns TD, Peay KG, Boynton PJ, Grubisha LC, Hynson NA, Nguyen NH, Rosenstock NP (2009) Inoculum potential of Rhizopogon spores increases with time over the first four years of a 99-year spore burial experiment. New Phytol 181:463-470

Burgess T, Dell B, Malajczuk N (1994) Variation in mycorrhizal development and growth-stimulation by 20 Pisolithus isolates inoculated on to Eucalyptus grandis W Hill Ex Maiden. New Phytol 127:731-739

Certini G (2005) Effects of fire on properties of forest soils: a review. Oecologia 143:1-10

Chesson PL, Warner RR (1981) Environmental variability promotes coexistence in lottery competitive-systems. Am Nat 117:923-943

Conover WJ, Johnson ME, Johnson MM (1981) A comparative study of tests for homogeneity of variances, with applications to the outer continental shelf bidding data. Technometrics 23:351-361

DeLuca TH, Sala A (2006) Frequent fire alters nitrogen transformations in ponderosa pine stands of the inland northwest. Ecology 87:2511-2522

DeLuca TH, MacKenzie MD, Gundale MJ, Holben WE (2006) Wildfire-produced charcoal directly influences nitrogen cycling in ponderosa pine forests. Soil Sci Soc Am J 70:448-453

Egger KN, Hibbett DS (2004) The evolutionary implications of exploitation in mycorrhizas. Can J Bot 82:1110-1121

Grogan P, Baar J, Bruns TD (2000a) Below-ground ectomycorrhizal community structure in a recently burned bishop pine forest. J Ecol 88:1051-1062

Grogan P, Bruns TD, Chapin FS (2000b) Fire effects on ecosystem nitrogen cycling in a Californian bishop pine forest. Oecologia 122:537-544

Hart SC, DeLuca TH, Newman GS, MacKenzie MD, Boyle SI (2005) Post-fire vegetative dynamics as drivers of microbial community structure and function in forest soils. Forest Ecol Manag 220:166-184

Herre EA, Knowlton N, Mueller UG, Rehner SA (1999) The evolution of mutualisms: exploring the paths between conflict and cooperation. Trends Ecol Evol 14:49-53

Hibbett DS, Gilbert LB, Donoghue MJ (2000) Evolutionary instability of ectomycorrhizal symbioses in basidiomycetes. Nature 407:506-508

Hobbie JE, Hobbie EA (2006) ${ }^{15} \mathrm{~N}$ in symbiotic fungi and plants estimates nitrogen and carbon flux rates in Arctic tundra. Ecology 87:823-828

Hoeksema JD, Schwartz MW (2003) Expanding comparativeadvantage biological market models: contingency of mutualism on partners' resource requirements and acquisition trade-offs. P Roy Soc B-Biol Sci 270:913919 
Hoeksema JD, Piculell BJ, Thompson JN (2009) Withinpopulation genetic variability in mycorrhizal interactions. Communicative and Integrative Biology 2:110-112

Horton TR, Bruns TD (2001) The molecular revolution in ectomycorrhizal ecology: peeking into the black-box. Mol Ecol 10:1855-1871

Horton TR, Cazares E, Bruns TD (1998) Ectomycorrhizal, vesicular-arbuscular and dark septate fungal colonization of bishop pine (Pinus muricata) seedlings in the first 5 months of growth after wildfire. Mycorrhiza 8:11-18

Hutchinson GE (1961) The paradox of the plankton. Am Nat 95:137-145

Ishida TA, Nara K, Hogetsu T (2007) Host effects on ectomycorrhizal fungal communities: insight from eight host species in mixed conifer-broadleaf forests. New Phytol 174:430-440

Izzo A, Canright M, Bruns TD (2006a) The effects of heat treatments on ectomycorrhizal resistant propagules and their ability to colonize bioassay seedlings. Mycol Res 110:196-202

Izzo A, Nguyen DT, Bruns TD (2006b) Spatial structure and richness of the ectomycorrhizal resistant propagule community colonizing hosts with differing seedling establishment patterns. Mycologia 98:374-383

Johnson NC (1993) Can fertilization of soil select less mutualistic mycorrhizae? Ecol Appl 3:749-757

Johnson NC, Graham JH, Smith FA (1997) Functioning of mycorrhizal associations along the mutualism-parasitism continuum. New Phytol 135:575-586

Jones MD, Smith SE (2004) Exploring functional definitions of mycorrhizas: are mycorrhizas always mutualisms? Can J Bot 82:1089-1109

Kennedy PG, Peay KG (2007) Different soil moisture conditions change the outcome of the ectomycorrhizal symbiosis between Rhizopogon species and Pinus muricata. Plant Soil 291:155-165

Kennedy PG, Bergemann SE, Hortal S, Bruns TD (2006) Determining the outcome of field-based competition between two Rhizopogon species using real-time PCR. Mol Ecol 4:881-890

Kennedy PG, Hortal S, Bergemann SE, Bruns TD (2007) Competitive interactions among three ectomycorrhizal fungi and their relation to host plant performance. J Ecol 95:1338-1345

Kennedy PG, Peay KG, Bruns TD (2009) Root tip competition among ectomycorrhizal fungi: are priority effects a rule or an exception? Ecology 90:2098-2107

Klironomos JN (2002) Feedback with soil biota contributes to plant rarity and invasiveness in communities. Nature 417:67-70

Lilleskov EA, Fahey TJ, Lovett GM (2001) Ectomycorrhizal fungal aboveground community change over an atmospheric nitrogen deposition gradient. Ecol Appl 11:397-410

Lilleskov EA, Fahey TJ, Horton TR, Lovett GM (2002) Belowground ectomycorrhizal fungal community change over a nitrogen deposition gradient in Alaska. Ecology 83:104-115

Lilleskov EA, Bruns TD, Horton TR, Taylor DL, Grogan P (2004) Detection of forest stand-level spatial structure in ectomycorrhizal fungal communities. FEMS Microbiol Ecol 49:319-332
Mahmood S, Finlay R, Wallander H, Erland S (2002) Ectomycorrhizal colonisation of roots and ash granules in a spruce forest treated with granulated wood ash. Forest Ecol Manag 160:65-74

Marx DH, Hatch AB, Mendicino JF (1977) High soil fertility decreases sucrose content and susceptibility of Loblollypine roots to ectomycorrhizal infection by Pisolithus tinctorius. Can J Bot 55:1569-1574

Molina R, Chamard J (1983) Use of the ectomycorrhizal fungus Laccaria laccata in forestry. II. Effects of fertilizer forms and levels on ectomycorrhizal development and growth of container-grown Douglas-fir and ponderosa pine seedlings. Can J Forest Res 13:89-95

Morris MH, Smith ME, Rizzo DM, Rejmanek M, Bledsoe CS (2008) Contrasting ectomycorrhizal fungal communities on the roots of co-occurring oaks (Quercus spp.) in a California woodland. New Phytol 178:167-176

Nara K (2006) Ectomycorrhizal networks and seedling establishment during early primary succession. New Phytol 169:169-178

Neary DG, Klopatek CC, DeBano LF, Ffolliott PF (1999) Fire effects on belowground sustainability: a review and synthesis. Forest Ecol Manag 122:51-71

Noë R, Hammerstein P (1995) Biological markets. Trends Ecol Evol 10:336-339

Park T (1954) Experimental studies of interspecies competition. II. Temperature, humidity, and competition in two species of Tribolium. Physiol Zool 27:177-238

Parrent JL, Vilgalys R (2007) Biomass and compositional responses of ectomycorrhizal fungal hyphae to elevated $\mathrm{CO}_{2}$ and nitrogen fertilization. New Phytol 176:164-174

Peay KG, Bruns TD, Kennedy PG, Bergemann SE, Garbelotto M (2007) A strong species-area relationship for eukaryotic soil microbes: island size matters for ectomycorrhizal fungi. Ecol Lett 10:470-480

Peay KG, Garbelotto M, Bruns TD (2009) Spore heat resistance plays an important role in disturbance mediated assemblage shift of ectomycorrhizal fungi colonizing Pinus muricata seedlings. J Ecol 97:537-547

Piculell BJ, Hoeksema JD, Thompson JN (2008) Interactions of biotic and abiotic environmental factors in an ectomycorrhizal symbiosis, and the potential for selection mosaics. BMC Biology 6:23. doi:10.1186/1741-7007-6-23

Pyne SJ, Andrews PL, Laven RD (1996) Introduction to wildland fire. Wiley, New York

Raison RJ (1979) Modification of the soil environment by vegetation fires, with particular reference to nitrogen transformations: a review. Plant Soil 51:73-108

Sachs JL, Mueller UG, Wilcox TP, Bull JJ (2004) The evolution of cooperation. Q Rev of Biol 79:135-160

Schwartz MW, Hoeksema JD (1998) Specialization and resource trade: biological markets as a model of mutualisms. Ecology 79:1029-1038

Setala H, Rissanen J, Markkola AM (1997) Conditional outcomes in the relationship between pine and ectomycorrhizal fungi in relation to biotic and abiotic environment. Oikos 80:112-122

Simon L, Bousquet J, Levesque RC, Lalonde M (1993) Origin and diversification of endomycorrhizal fungi and coincidence with vascular land plants. Nature 363:67-69

Smith SE, Read DJ (1997) Mycorrhizal symbiosis, 2nd edn. Academic, New York 
St. John TV, Rundel PW (1976) The role of fire as a mineralizing agent in a Sierran coniferous forest. Oecologia 25:35-45

Stachowicz JJ (2001) Mutualism, facilitation, and the structure of ecological communities. Bioscience 51:235-246

Stenstrom E, Ek M, Unestam T (1990) Variation in field response of Pinus sylvestris to nursery inoculation with four different ectomycorrhizal fungi. Can J Forest Res Research 20:1796-1803

Sugihara NG, van Wagtendonk JW, Shaffer KE, FitesKauffman J, Thode AE (eds) (2006) Fire in California's ecosystems. University of California Press, Berkeley

Team RCD (2008) R: a language and environment for statistical computing. R Foundation for Statistical Computing, Vienna, Austria

Termorshuizen AJ, Ket PC (1989) The effects of fertilization with ammonium and nitrate on mycorrhizal seedlings of Pinus sylvestris. Agr Ecosyst Environ 28:497-501
Tryon EH (1948) Effect of charcoal on certain physical, chemical and biological properties of forest soils. Ecol Monogr 18:81-115

Wallander H, Nylund JE (1991) Effects of excess nitrogen on carbohydrate concentration and mycorrhizal development of Pinus sylvestris L seedlings. New Phytol 119:405-411

Wallander H, Nylund JE (1992) Effects of excess nitrogen and phosphorus starvation on the extramatrical mycelium of ectomycorrhizas of Pinus sylvestris L. New Phytol 120:495-503

Wiens JA (1977) On competition and variable environment. Am Sci 65:590-597

Zhou MY, Sharik TL (1997) Ectomycorrhizal associations of northern red oak (Quercus rubra) seedlings along an environmental gradient. Can J Forest Res Research 27:1705-1713 